\title{
The Role of Summer Intensive Programmes on Improving Students' Learning Outcomes in Rural Areas
}

\author{
https://doi.org/10.3991/ijet.v16i06.18713 \\ Zhailagul Sagyndykova ${ }^{(凶)}$ \\ Narxoz University, Almaty, Kazakhstan \\ zhailagul@gmail.com \\ Bella Gazdiyeva, Zarina Gabdullina \\ Sh.Ualikhanov Kokshetau State University, Kokshetau, Kazakhstan \\ Aida Akhmetzhanova \\ JSC "Information and Analytical Center", Nur-Sultan, Kazakhstan \\ Damel Mektepbayeva \\ Nazarbayev University, Nur-Sultan, Kazakhstan \\ Abraham Althonayan \\ Brunel University London, London, United Kingdom
}

\begin{abstract}
Many countries face serious challenges with education in rural areas. Vast majority of education in rural areas are disadvantaged. In Kazakhstan, ineffective outcomes of education in rural areas impact on most rural students are lack employability and entrepreneurial skills. This research investigates the role of intensive summer programmes on improving students' learning outcomes aim to develop and Inspire employability and entrepreneurial skills and STEAM-education in rural schools of Kazakhstan. This research suggest that the summer program transferred practical skills and knowledge to students, while increasing their motivation to learn outside of the classroom in a way that traditional educational system has not. There are social and economic challenges in the rural areas: unemployment, the lack of highly skilled professionals, and low motivation. Summer programs appear to address all above issues by motivating youth to learn and providing them with practical skills that can be used in their private life and careers.
\end{abstract}

Keywords-Summer schools, rural education, STEAM-education, career choice

\section{$1 \quad$ Introduction}

It is an ongoing question if summer school is a perfect time to catch up with complex topics and promote education in an informal environment. Numerous studies discussed the beneficial effects of various summer programmes leading to more 
meaningful and coherent learning, increased creativity, critical thinking and motivation $[1,2,3]$.

The research project "Developing and Inspiring Entrepreneurial and STEAM Education in Rural Schools of Kazakhstan" started in 2016 and is a funded project by the Ministry of Education and Science of the Republic of Kazakhstan to encourage engineering and art programmes in Rodina province school in Kazakhstan, was chosen as a model platform for other rural schools in the nearest districts. The project team conducts a study to estimate the effectiveness of summer programmes. The purpose of the study is to examine the results of a one-week summer program in the rural school that has been conducted during a 4-year period. Rural school at Rodina was the first to introduce the concept of summer schools in Kazakhstan and this study represents the first opportunity for readers of management in education journals to learn about the results of such concept in Kazakhstan. Many researchers attempts to analyse the rural education though distance learning, out-of-school learning groups, studies on effectiveness of intervention schools and rural development through rural education $[4,5$, $6,7]$.

The study was conducted in the rural area as the biggest cities in the country have a huge variety of ways to improve the level of knowledge which include additional courses and tutors. Rural areas in majority of cases lack such possibilities and a school usually is the only place to get knowledge due to the lack of internet and possibility of online education. In 2007, OECD recommended developing access programmes for rural and low-income students but the OECD report in 2017 showed no such existed programs in Kazakhstan [8]. Moreover, according to the statistical data the number of unemployed youth is growing and has reached 3,8\% in 2020 [9]. Such situation creates the unfavourable environment in rural area with the main goal to leave the village for a better life and migrate to main cities. Such migration creates further challenges such as congestion, urbanisation, high coast of development and risk management.

Several studies indicated that summer schools have various effects depending on age of students, type of school, country. Overall, summer schools seem to have a much greater effect on low-performing students [1]. In the United States of America (US), the increase of the number of summer schools for disadvantaged students, most of whom are from low-income and ethnic minority families in the way led to an upgrade the learning abilities and career development opportunities [3]. And even though it is worth to note that summer studying can be beneficial not only to lowincome students, however, some argued that summer vacation leads to loss of knowledge and skills in general [10, 11], majority of studies [1,2,3] indicated that summer schools leads to improve students' grades in the flowing terms. However, often the results can be rather intangible and benefits can come from more positive attitude to school or classes in general. The following study was conducted to evaluate both the students' and the teachers' perspective.

The entrepreneurial and STEAM-education as well as development of soft skills were chosen this study for several purposes. It is highly recognized that integration of Science, Technology, Engineering, Art, and Mathematics (STEM or STEAM) in school curriculum is an essential step in education considering the interdisciplinary 
nature of science and research in recent years $[12,13,14]$. Such multi-disciplinary concept allows students to get knowledge and solve tasks from different perspectives and connect them to real-world problems. Multi-disciplinary approach helps to foster communication across disciplines and integrate various contents to solve complex problems [15]. The importance of entrepreneurial skills and competences have also been extensively discussed in the last century $[16,17]$. However, most of the school education in Kazakhstan still does not include entrepreneurship. Soft skills development is also lacking in the existing educational system. Pupils learn soft skills including, communicative and public speaking, teamwork and critical thinking only if they attend additional classes outside of school. Again, students from low-income families and rural area are disadvantaged and unlikely to have the opportunity to give these soft skills which are key employability skills.

The current needs for summer schools in Kazakhstan is driven by the fact that Kazakhstan's education system goes through a transitional period after leaving Soviet Union system in early 1990s but did not fully acquire the new education system. This study is aimed to present the outcomes of Rodina province summer school as a prototype for its further adaptation on a national level. Moreover, due to mind-set and structural similarities such as similar environments, education systems, language and culture this study can be easily replicated in many schools post-Soviet Union countries and have a much broader impact.

\section{Methodology}

\subsection{Aim and significance of the study}

The aim of the research is to analyse the role of the summer school in the rural area. The following research questions are addressed in the paper: How effective summer learning programmes on improving students' skills? What are the main elements of the summer programmes? What is the impact of the summer schools on student learning outcomes? What are the main enablers and challenges of summer learning programmes implementation?

To analyse the effectiveness on children's achievement the questionnaire was conducted with 127 participants and interviews of the instructors. The feedback of each summer intensive development programmes was assessed based on the challenges and the learning elements that were improved during the following year in the summer programs to improve the students' performance.

\subsection{Study design}

There are several factors that may influence the effectiveness of a summer intensive development programme. The main factors include, Instructional time, the curriculum content, and the quality of teaching were highlighted based on Rand Education research [1]. Studies show that adding time for learning does not always lead to notable learning improvements, while curriculum and instruction promoting every day 
engagement tends to have a much bigger impact [18]. Another study [19, p. 11-21] was focused on four specific programme components: PBL, high integration of academic and enrichment experiences, partnering with schools and local establishments throughout NIOST. It revealed other factors that correlated with the effectiveness of summer schools: students' behaviour and namely his or her wish to be engaged to make their school beneficial. Moreover, internal factors such as leadership and staff dedication can be essential in effective summer school programme. Another important factor is logistics such as transportation and food, how about facility, school environment, cleanses, playground, laps, internet, PCs [20, 21]. These factors can positively affect the students' participation and engagement [22].

In June, 2016 the Rodina rural school launched a new initiative to help prospective students from rural communities across the region to learn about leadership and motivation, and to improve their English language skills. The summer programme was the first iteration of a three-year pilot targeting students from the Akmola region in Kazakhstan. Twenty students from rural high schools were hosted on the school campus for the summer programme. This initiative was supported by the school administration and a local business. The programme took the form of a 5-day workshop on a wide range of topics, including Global English, how to complete a CV and how to write a motivation letter for college applications. The programme was considered to be unique and beneficial by both the teaching staff and the students.

In June, 2017, the summer programme was devoted to English language competency development and critical thinking skills formation. The students were engaged in based on blended learning including: village quest, watching movies, videos and podcasts on global topics, and groups work. The tutors were two highly-qualified English teachers who had obtained postgraduate degrees from $\mathrm{UK}$, as well as two $\mathrm{PhD}$ faculty members from Kokshetau State University (Kazakhstan).

In 2018, the summer programme conducted one-week summer activities; however, it was designed to bridge the gap between the hard skills and soft skills and thus was comprised of more multidiscipline modules including: engineering, public speaking, self-branding, book dating, and yoga classes. Participants were encouraged to take a whole week of English classes after the main modules. While the first two years were oriented toward high school graduates, this year's programme was oriented toward schoolchildren between the ages of 8 and 15. Accordingly, enrolment increased to 60 participants in 2018. This iteration presented a new concept of various speakers and topics needed to develop a comprehensive summer school in a rural area.

"Make it smART by APA \& friends" summer programme in 2019 included morning yoga classes, art therapy classes, Spanish and English classes, creative entrepreneurship and successful career workshops, positive creation of a self-concept class. A number of 48 children from the neighbouring schools enrolled in this class, and the teaching staff increased significantly, 10 professionals who were educated abroad.

The students' attendance for all summer schools was voluntary and free for the local residents. The children from the nearby were transported by the school bus every day. 
Table 1. Lists the summer programmes' elements under analysis. Source: [1, p. 29-30].

\begin{tabular}{|c|c|c|c|c|}
\hline Area of study & 1-year & 2-year & 3-rd year & $4^{\text {th }}$ year \\
\hline $\begin{array}{c}\text { Name of a } \\
\text { programme }\end{array}$ & $\begin{array}{c}\text { Summer camp in } \\
\text { Leadership }\end{array}$ & $\begin{array}{c}\text { "Global } \\
\text { English" }\end{array}$ & "You can STE@M It" & "Make it smART" \\
\hline $\begin{array}{l}\text { Years of } \\
\text { programme }\end{array}$ & 2016 & 2017 & 2018 & 2019 \\
\hline $\begin{array}{l}\text { Programme } \\
\text { goal }\end{array}$ & $\begin{array}{l}\text { To develop leader- } \\
\text { ship skills }\end{array}$ & $\begin{array}{l}\text { To develop global } \\
\text { thinking through } \\
\text { learning English }\end{array}$ & $\begin{array}{l}\text { To develop STEAM } \\
\text { and entrepreneurial } \\
\text { skills }\end{array}$ & $\begin{array}{l}\text { To develop soft skills } \\
\text { and improve English } \\
\text { language competencies }\end{array}$ \\
\hline $\begin{array}{l}\text { Target popu- } \\
\text { lation }\end{array}$ & $\begin{array}{l}\text { Rodina province } \\
\text { schoolchildren }\end{array}$ & $\begin{array}{l}\text { Rodina province } \\
\text { schoolchildren }\end{array}$ & $\begin{array}{l}\text { Rodina province } \\
\text { schoolchildren and } \\
\text { children from neigh- } \\
\text { bouring villages }\end{array}$ & $\begin{array}{l}\text { Rodina province } \\
\text { schoolchildren and } \\
\text { children from neigh- } \\
\text { bouring villages }\end{array}$ \\
\hline $\begin{array}{l}\text { Number of } \\
\text { students } \\
\text { served }\end{array}$ & 20 & 40 & 60 & 48 \\
\hline $\begin{array}{l}\text { Cost to fami- } \\
\text { lies }\end{array}$ & Cost free & Cost free & Cost free & Cost free \\
\hline $\begin{array}{l}\text { Type of the } \\
\text { program }\end{array}$ & Educational & Educational & Educational & Educational \\
\hline Content & $\begin{array}{l}\text { English speaking } \\
\text { skills, goal setting } \\
\text { and implementation } \\
\text { and motivation letter } \\
\text { writing, lessons on } \\
\text { how to be a leader }\end{array}$ & $\begin{array}{l}\text { English classes, out- } \\
\text { door activities, quests, } \\
\text { workshops }\end{array}$ & $\begin{array}{l}\text { Yoga classes, book } \\
\text { dating, English clas- } \\
\text { ses, outdoor activities, } \\
\text { quests, science classes, } \\
\text { public speaking work- } \\
\text { shops, meetings with } \\
\text { successful people }\end{array}$ & $\begin{array}{l}\text { Yoga classes, English } \\
\text { and Spanish classes, } \\
\text { outdoor activities, art } \\
\text { therapy, quests, intro- } \\
\text { duction to IELTS, } \\
\text { team-building work- } \\
\text { shops, meetings with } \\
\text { successful people }\end{array}$ \\
\hline Teaching staff & \begin{tabular}{|l|} 
Internationally \\
trained profession- \\
als, Masters of Arts, \\
PhD, Bolashak \\
International Schol- \\
arship graduates \\
\end{tabular} & $\begin{array}{l}\text { Internationally trained } \\
\text { professionals, Masters } \\
\text { of Arts, PhD, Bolashak } \\
\text { International Scholar- } \\
\text { ship graduates }\end{array}$ & $\begin{array}{l}\text { Internationally trained } \\
\text { professionals, Masters } \\
\text { of Arts, PhD, Bolashak } \\
\text { International Scholar- } \\
\text { ship graduates }\end{array}$ & $\begin{array}{l}\text { Internationally trained } \\
\text { professionals, Masters } \\
\text { of Arts, PhD, Bolashak } \\
\text { International Scholar- } \\
\text { ship graduates }\end{array}$ \\
\hline Outcomes & $\begin{array}{l}\text { Learn how to com- } \\
\text { pile his/her diary, a } \\
\text { CV, how to achieve } \\
\text { goals, English } \\
\text { vocabulary }\end{array}$ & $\begin{array}{l}\text { Read articles on } 17 \\
\text { MILLENIUM sustain- } \\
\text { able development } \\
\text { goals (SDG), learnt to } \\
\text { work in groups, partic- } \\
\text { ipated in discussion in } \\
\text { English }\end{array}$ & $\begin{array}{l}\text { Attended classes of } 6 \\
\text { motivational speakers, } \\
\text { presented entrepre- } \\
\text { neurial projects }\end{array}$ & \begin{tabular}{|l|} 
Attended one week \\
morning yoga classes, \\
art therapy classes, \\
learnt English on \\
different levels and \\
talked to 6 motivation- \\
al speakers and volun- \\
teers on how to be \\
successful
\end{tabular} \\
\hline
\end{tabular}

\section{$3 \quad$ Results and Discussion}

Individual interviews and the questionnaire on efficiency of the summer programme and the impact of the summer school on the village development were conducted.

The group of respondents consists of 127 students, aged 10 to 17 , who attended the summer school during the 4th-year period. Eighty-five percent of these respondents 
were from Rodina village, while the remaining fifteen percent were from the neighbouring villages.

Eleven percent $(11 \%)$ of the questioned participated three times in the summer school, $46 \%$ - 2 times and $43 \%$ took part once. The majority of respondents (50\%) indicated that they attended English classes, while five percent attended Yoga classes, two percent quests, two percent participated in all activities, and the remaining fortyone percent either did not abstain from specifying which components they attended.

\section{Do you think that the summer school was useful for you?}

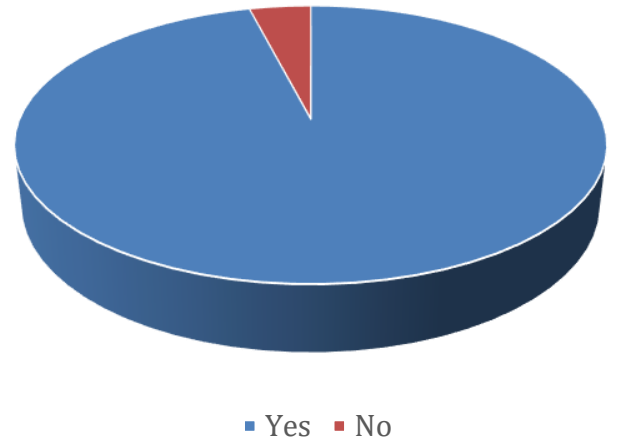

Fig. 1. Do you think that the summer school was useful for you?

Ninety-six percent of respondents responded positively, while four percent responded negatively. Thus, the vast majority of participating students thought that the summer program was beneficial for them. 


\section{Did you benefit of the summer school?}

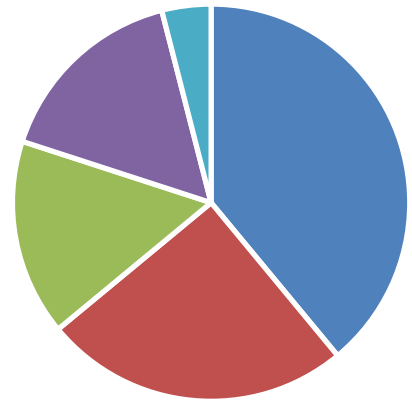

- Improved my English

- Learning new information and skills

- Improved understanding of physics

- Getting to know new people

- Influenced my life

Fig. 2. Did you benefit of the summer school?

Thirty-nine per cent of respondents reported that the summer program improved their English skills. Twenty-five percent reported learning new information and skills apart from English with 16 percent reporting improved understanding of physics and sixteen percent reported getting to know new people, however, the small proportion of those 4 percent of who thought that the summer school influenced their lives, enjoyed yoga and considered the summer school more difficult than in-school time.

The questionnaire results demonstrate that the half of the participants (50\%) improved their English vocabulary, pronunciation, sentence writing, and numbers, grammar, understanding of the English alphabet. Around eighteen percent of students improved their speaking skills, while $14 \%$ reported learning how effectively communicate in English, and ten percent reported improving their ability to express their thoughts in English. Eight percent of participants reported that they did not learn anything. 


\section{What did you learn in the summer program?}

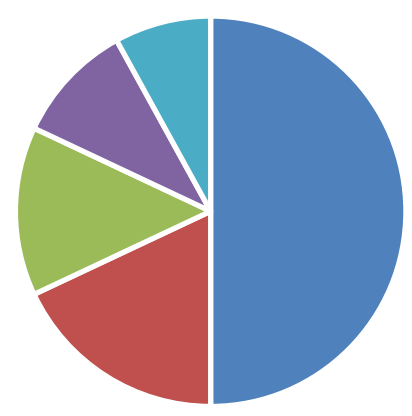

- Improved: vocabulary, pronunciation, sentence writing, and numbers, grammar, understanding of the English alphabet

- Speaking skills

- Learning how to effectively communicate in English,

- Improved the ability to express their thoughts in English

Fig. 3. What did you learn in the summer program? 


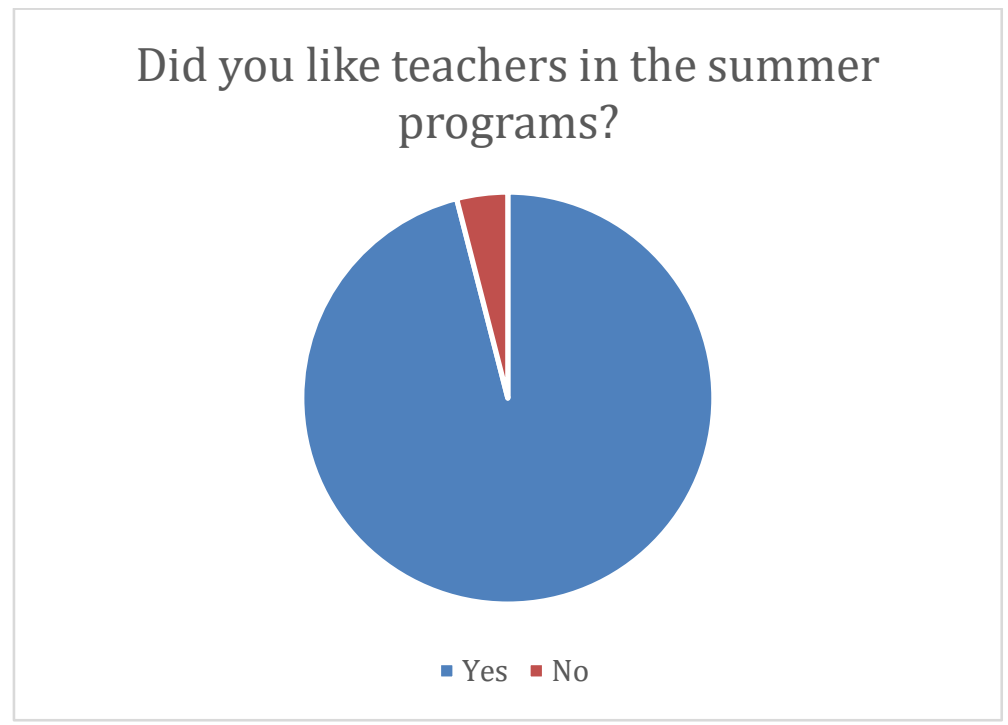

Fig. 4. Did you like teachers in the summer programs?

Ninety-six percent of schoolchildren reported satisfaction with the methods of teaching and teachers' attitudes towards them. Merely four percent of the respondents responded negatively. The other respondents described their teachers as kind, pleasant, energetic, responsive, and open. They replied that their teachers eagerly explained new topics to them, engaged them in class, and made learning fun for them.

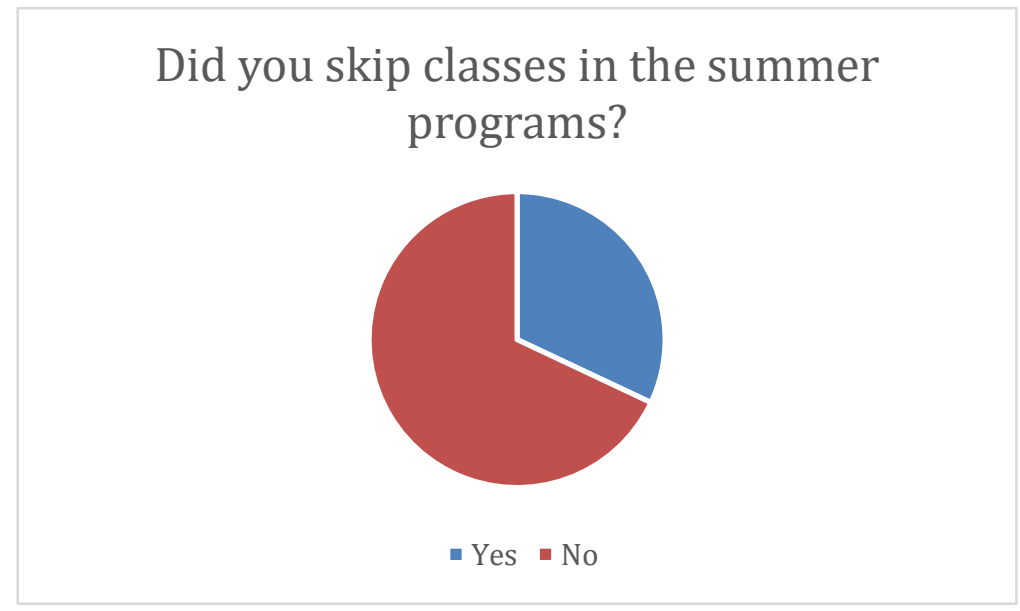

Fig. 5. Did you skip classes during the summer programs?

One third of participants (32\%) missed classes when they were out of the village, sick, or dealing with various family circumstances. The general levels of interest in 
summer school is indicated by the fact that the majority of the attendees $(68 \%)$ wished to participate fully in the summer school.

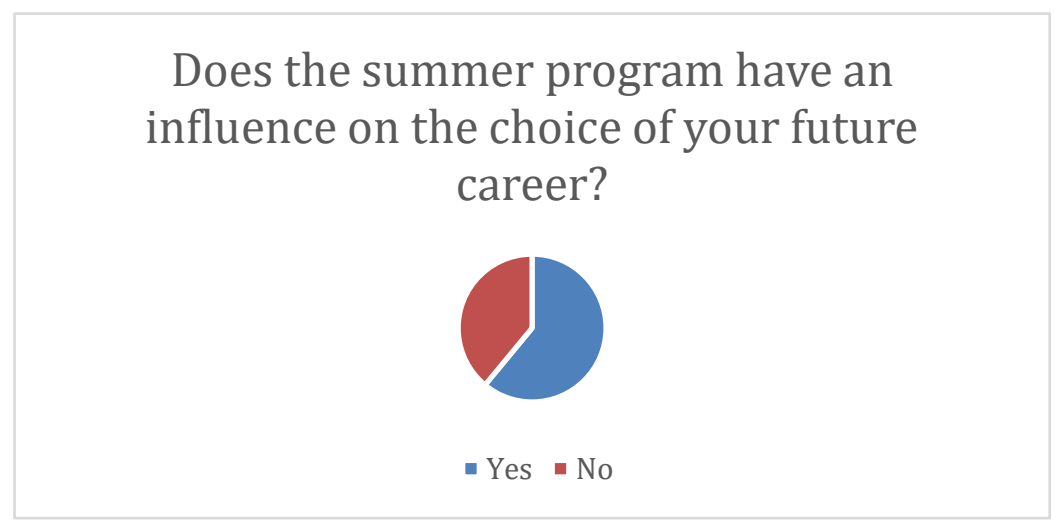

Fig. 6. Does the summer program have an influence on the choice of your future career?

Twenty-one percent of survey respondents can identify positively the impact of the summer school, twenty-five percent of respondents started to express love for learning English. Additionally, fifteen percent of respondents reported greater realization of the connection between their future profession and the English language. Thirty-nine percent of the respondents could not connect the outcomes of the summer school with their future careers.

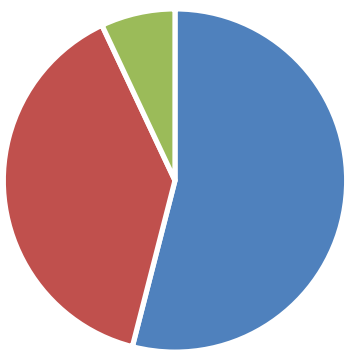 \\ - No $\because$ Yes $=$ Other}

Can you give your suggestions on improvement of the summer program?

Fig. 7. Can you give your suggestions on improvement of the summer program?

Fifty-four percent of respondents reported not wanting to change anything, because they were happy with what they were offered. On the other hand, thirty-nine percent suggested a more individualized learning approach for each student, more individual 
classes, greater diversity in speakers, more classes in biology and math, and change the learning environment by conducting classes in open air. Seven percent indicated their wish to study at school.

Another interview was conducted among the program's first participants who left the summer program two to three years ago. The goal of the interview was to assess how effective the summer schools was, whether the summer school influenced the choice of participants' professions or studies. There were four participants in this interview via phone calls, all of whom have become university students. They highlighted the significance of the school in learning the English language.

[Student \#1]

I learnt new expressions, phrases and pronunciation of some words. The teachers were funny; they wanted us to remember the assigned tasks and motivated us.

The summer school has not helped me in choosing the profession.

We learned to work in groups, learn new words, we spoke about ourselves and teachers helped us to talk. Thanks to the friendly atmosphere, the learning process was engaging and productive.

\section{[Student \#2]}

The summer school was useful. First, it is learning English, and second, I learnt new information about different universities abroad. The summer school did not influence my choice because I study at the Eurasia National University to be a teacher of the Russian Language and Literature. But with their English clubs I improved English significantly.

I liked the summer school because the teachers were like us, they were on the same ground. I felt like they were my friends. We were one team.

[Student \#3]

I attended the summer program once. I learnt how to plan my day and manage my time. I learnt many new words and collocations. I became friends with new people. The summer school did influence my choice of the profession.

The teachers are kind and responsive people. I am happy to know them. I continue taking English classes. English will help my profession.

[Student \#4]

I attended the summer program only one time. I was taught how to plan and write projects. The summer school was useful for me. I learnt many new things, new vocabulary and grammar. It helped to identify myself from another side. It gives an opportunity to meet new people. The summer school motivated me to learn English further and played a significant role in the choice of the profession. I am going to become an English teacher. The teachers of the summer school are very energetic, communicative and open people. They are ready to help any time. I am happy that I still keep in touch with some of them.

Five teachers of the summer schools were interviewed and responded to nine questions focused on teaching challenges, the need for and effectiveness of the summer program, methodologies they used in class, motivation to participate in the summer school and recommendations to improve the summer programme. The teachers' experience varied, with two teachers having 16 years' experience in teaching English, and three young professionals, two of whom were graduates of Nottingham University in 
Master of Arts. One teacher took part only once training writing and English, the others taught English, Self-branding, Leadership, Public Speaking, Book Dating, Quests and OpenAir Games. Among the difficulties the trainers highlight the different levels of the English language acquisition while two indicated the low level of the language proficiency of the schoolchildren, lack of self-confidence, and lack of motivation limiting factors to the program's success. The respondents positively reacted to the question of the outcomes of the summer school, stating that the summer program allowed children to learn an abundance of English vocabulary, practice speaking on topics of their interest in English (e.g., Space, Fashion, Technology), and gain knowledge about study abroad opportunities. Teamwork, case studies, presentations and games, differentiation in education, compilation of descriptors became the major tools the teachers introduced in class. Respondents pointed to the of classes - from yoga, art therapy, to English and Spanish as a major advantage of this program. It is vitally important to build a vision of the summer school programmes creating them as that of flexible, holistic, and creative. Because youth spend the vast majority of their time outside of the school context, academic success is inextricably linked to nonschool factors and experiences [2, p.16]. One of the trainers undermines freedom from strict methods of learning, they were free to create a class in their own way. Meanwhile the teachers suggest that summer school should embrace larger quantities of participants of the summer programs, launch winter schools, attract international teachers, and enlarge the period of the program to three weeks, to make small classes to have a chance to reach every student. The most important claim was to involve companies and government for sponsorship to increase the impact of the schools on the country.

These results of the questionnaire, the interviews of the students and the teachers revealed willingness of the rural students to acquire knowledge in the summer period, understanding the positive impact of extracurricular learning, while some comment that the summer school did not have any influence on their future career or helped in some way. It should be also noted that teachers' suggestions were to attract corporate sponsors claiming that it would involve more rural children to afterschool activities.

\section{Conclusion}

The results of this research indicate that the summer education programme has had a positive effect on rural student and community of Rodina and neighbouring villages. The research also suggests that the summer programme has potential to supersede the limitations of the outcomes of education in rural Kazakhstan. Because summer school programme managed by motivated professionals who worked independently from Kazakh Ministry of Education and were thus free from numerous bureaucratic inhibitions. In this summer school programme same teachers have been chosen annual summer school, an effective approach to promote internal analysis, review and continue. Moreover, the local authorities and business community provided necessary logistics to give a financial support to the project. This research offers a prototype of a 
summer school for policymakers and educational specialists by presenting a working methodology for summer schools in the region.

In future years, the variety of summer programmes that teachers and organisers collaboratively designed every year could create a sound environment around the school, participants and teachers in numerous regions both within Kazakhstan and in neighbouring regions. For such dissemination to be feasibly and effectively implemented, future studies and related initiatives should address two key issues: funding limitations and key teaching challenges that programme teachers encountered throughout this programme. Collaborative support for the continuation of the summer school in Rodina and surrounding areas should address both issues by enabling the continuation of systematic effectiveness of studies and measurement of return investment in the summer programme in the improving the effectiveness of learning outcomes. By optimising summer programme on a local level, it would be more feasible to benchmark and sustain the summer school model to other rural regions of Kazakhstan and beyond.

\section{$5 \quad$ References}

[1] Sloan McCombs, J.S., H. Augustine, C., L. Schwartz, H., J. Bodilly, S., McInnis, B., S. Lichter, D., \& Brown Cross, A. (2011). Making summer count: how summer programs can boost children's learning. Santa Monica: Rand Corporation. https://doi.org/10.1037/ e525802012-001

[2] Bazrafcan, L., Haghani, F., \& Shokrpour, N. (2014). The summer school students' viewpoints about important factors in learning. Journal of Advances in Medical Education and Professionalism, 2(2): 77-81.

[3] Knopf, J.A., Hahn, R.A., Proia K.K., Truman, B.I., Johnson, R.L., Muntaner, C., Fielding, J. E., Jones, C. P., Fullilove, M. T., Hunt, P. C., Qu, S., Chattopadhyay, S. K., Milstein, B., Community Preventive Services Task Force (2015). Out-of-school-time academic programs to improve school achievement: a community guide health equity systematic review. Journal of Public Health Management and Practice, 21(6): 594-608. https://doi.org/ $\underline{10.1097 / \mathrm{phh} .0000000000000268}$

[4] Lee, S.C., Nugent, G., Kunz, G.M., Houston, J., De Chenne-Peters, S.E. (2018). Case study: value-added benefit of distance-based instructional coaching on science teachers' inquiry instruction in rural school. Journal of Science Teacher Education, 29 (3): 179-199. https://doi.org/10.1080/1046560x.2018.1432226

[5] Power, S., Taylor, C., Rees, G., Jones, K. (2009). Out-of-school learning: variations in provision and participation in secondary schools. Research Paper in Education, 24(4): 439460. https://doi.org/10.1080/02671520802584095

[6] Hamm, J.V., Farmer, T. W., Robertson, D., Dadisman, K. A., Murray, A. (2010). Effects of a developmentally based intervention with teachers on native American and white early adolescents' schooling adjustment in rural settings. The Journal of Experimental Education, 78(3): 343-377. https://doi.org/10.1080/00220970903548038

[7] Schafft, K.A. (2016). Rural education as rural development: understanding the rural school-community well-being linkage in a 21 st-century policy context. Peabody Journal of Education, 91(2): 137-154. https://doi.org/10.1080/0161956x.2016.1151734

[8] OECD (2017). Higher Education in Kazakhstan 2017. Reviews of National Policies for Education, p. 126. 
[9] Ranking KZ (2020). There are more and more unemployed young men and women in the country: their number grew by $3.4 \%$ over the year. Available at: http://ranking.kz/ru/a/infopovody/v-strane-vsyo-bolshe-bezrabotnyh-yunoshej-i-devushekza-god-ih-kolichestvo-vyroslo-na-34 (Accessed June 12, 2020)

[10] Cooper, H., Nye, B., Charlton, K., Lindsay, J., Greathouse, S. (1996). The effects of summer vacation on achievement test scores: A narrative and meta-analytic review. Review of Education Research, 66(3): 227-268. https://doi.org/10.3102/00346543066003227

[11] Pelavin, S., \& David, J. (1977). Evaluating long-term achievement. An analysis of longitudinal data from compensatory education programs. Menlo Park: Stanford Research Institute.

[12] Baxter, J. A., Ruzicka, A., Beghetto, R. A., Livelybrooks, D. (2014). Professional development strategically connecting mathematics and science: The impact on teachers' confidence and practice. School Science and Mathematics, 114(3): 102-113. https://doi.org/10. $1111 / \mathrm{ssm} .12060$

Brophy, S., Klein, S., Portsmore, M., Rogers, C. (2008). Advancing engineering education in P-12 classrooms. Journal of Engineering Education, 97 (3): 369-387. https://doi.org/ 10.1002/j.2168-9830.2008.tb00985.x

[13] Cervetti, G. N., Barber, J., Dorph, R., Pearson, P. D., Goldschmidt, P.G. (2012). The impact of an integrated approach to science and literacy in elementary school classrooms. Journal of Research in Science Teaching, 49(5): 631-658. https://doi.org/10.1002/tea. $\underline{21015}$

[14] Harris, A., de Bruin, L.R. (2018). Secondary school creativity, teacher practice and stem education: an international study. Journal of Educational Change, 19(2): 153-179. https:// doi.org/10.1007/s10833-017-9311-2

[15] Kirchhoff, B.A. (1994). Entrepreneurship and Dynamic Capitalism: The Economics of Business Firm Formation and Growth. Westport: Praeger.

[16] Harms, R., Grichnik, D. (2007). Zur Zukunft der deutschsprachigen Entrepreneurshipforschung - Strategien und thematische Schwerpunkte [On the future of Germanspeaking entrepreneurship research strategies and thematic priorities]. Zeitschrift für KMU \& Entrepreneurship, 55 (4), 266-275.

[17] Aronson, J., Zimmerman, J., Carlos, L. (1998). Improving student achievement by extending school: is it just a matter of time? Paper presented at PACE Media Education Writers Seminar, San Francisco, CA.

[18] Hall, G., Poston, K. F., Dennehy, J. (2017). Summer learning programs: investigating strengths and challenges. In: N. L. Deutsch (Eds.). After-school programs to promote positive youth development: learning from specific models, Advances in child and family policy and practice. Springer: Cham, pp. 1 - 21. https://doi.org/10.1007/978-3-319-59141-4_1

[19] Anisimova, T.I., Sabirova, F.M., Shatunova, O.V. (2020). Formation of Design and Research Competencies in Future Teachers in the Framework of STEAM Education. International Journal of Emerging Technologies in Learning, 15(2): 204-217. https://doi.org/ $\underline{10.3991 / i j e t . v 15 i 02.11537}$

[20] Orthaber, M., Stütz, D., Antretter, T., Ebner, M. (2020). Concepts for E-Assessments in STEM on the Example of Engineering Mechanics. International Journal of Emerging Technologies in Learning, 15(12): 136-152. https://doi.org/10.3991/ijet.v15i12.13725

[21] Malcik, M., Miklosikova, M. (2019). Study Results of University Students in the Context of Experiencing Positive Emotions, Satisfaction and Happiness. International Journal of Emerging Technologies in Learning, 14(23): 260-269. https://doi.org/10.3991/ijet.v14i23. $\underline{10882}$ 


\section{Authors}

Zhailagul Sagyndykova is a Cand. Sc. (Philology), Associate Professor of the Linguistic Center and Head of International Development and Partnership Department of Narxoz University, Almaty, Kazakhstan.

Bella Gazdiyeva is a Cand. Sc. (Philology), Associate Professor, Lecturer of the Department of Russian Philology and Library Science of Sh.Ualikhanov Kokshetau State University, Kokshetau, Kazakhstan.

Zarina Gabdullina is a Master, Lecturer of the Department of English and Teaching Methods at Sh.Ualikhanov Kokshetau State University, Kokshetau, Kazakhstan.

Aida Akhmetzhanova is a Deputy Director of the Department of Analytics, Monitoring and Evaluation at JSC "Information and Analytical Center", Nur-Sultan, Kazakhstan.

Damel Mektepbayeva is a Master, Senior Manager of Department of Development of the Innovation Ecosystem at Nazarbayev University, Nur-Sultan, Kazakhstan.

Abraham Althonayan is PhD, Senior Lecturer in Operations and Strategic Management and Lecture on the MBA at Brunel Business School at Brunel University London, London, United Kingdom.

Article submitted 2020-09-21. Resubmitted 2020-11-04. Final acceptance 2020-11-05. Final version published as submitted by the authors. 